\title{
IbM KELOMPOK PEMBUAT KERUPUK KERANG DESA PEPE KABUPATEN SIDOARJO
}

\author{
Sukarjati dan ${ }^{1)}$, Tony Susilo Wibowo ${ }^{2)}$ \\ ${ }^{1}$ Prodi Biologi FMIPA Universitas PGRI Adi Buana Surabaya \\ ${ }^{2}$ Prodi manajemen Fakultas Ekonomi Universitas PGRI Adi Buana Surabaya \\ Email:.'Sukarjati@ymail.com, ${ }^{2}$ tonysus_sw@unipasby.ac.id
}

\begin{abstract}
Abstrak
Kerupuk kerang belum dipasarkan secara luas padahal rasanya enak dan mempunyai nilai gizi yang tinggi sehingga berpotensi untuk dikembangkan. Di desa Pepe Kec. Sedati, Kab. Sidoarjo ada pembuat kerupuk kerang. Di desa Pepe juga ada penjual kerang darah bercangkang dan kerang darah kupas serta banyak buruh pengupas kerang darah. Kegiatan IbM ini bertujuan meningkatkan pendapatan pembuat kerupuk kerang di desa Pepe. Hasil Kegiatan Pengabdian yang telah dilakukan adalah melakukan pendampingan pemilihan bahan baku yaitu kerang yang berkualitas. 2.pendampingan pembuatan kerupuk kerang yang hygienis, 3. Melakukan pendampingan cara memperoleh PIRT. 4. Memberikan alat pencetak kerupuk. 5. Memberikan alat pengaduk kerupuk.
\end{abstract}

Kata kunci: Kerupuk kerang, Kerupuk kerang dengan campuran wortel, perajang kerupuk

\begin{abstract}
Shellfish crackers have not been widely marketed even though it tastes good and has high nutritional value so it has the potential to be developed. In the village of Pepe Kec. Sedati, Kab. Sidoarjo is a maker of shellfish crackers. In the village of Pepe there are also sellers of shells and shells of blood shells peeled and many workers to peel blood shells. This IbM activity aims to increase the income of conch cracker makers in Pepe village. The results of the Community Service Activities that have been carried out are assisting in the selection of raw materials namely quality shells. 2. assisting in making hygienic shell crackers, 3. Assisting how to obtain PIRT. 4. Providing cracker printing equipment. 5. Give the cracker mixer.
\end{abstract}

Keywords: Shellfish crackers, Shellfish crackers with a mixture of carrots, cracker chopers

\section{PENDAHULUAN}

Kerupuk kerang jarang ada di pasaran. Kerupuk yang banyak dipasaran adalah kerupuk udang, kerupuk ikan, kerupuk kupang, kerupuk bawang serta kerupuk sayur. Kerupuk kerupuk tersebut di buat hanya dari air kaldunya saja tanpa menyertakan dagingnya sedangkan kalau kerupuk kerang bahan bakunya adalah kerang bukan hanya kaldu kerang. Kerang darah memiliki kandungan protein yang cukup tinggi yaitu 12-14\% (Mubarak, 1997). Menurut Snswiasri (1993) kerang merupakan sumber protein, vitamin, mineral dan asam lemak tak jenuh yang merupakan bahan pangan dengan nilai gizi tinggi bagi masyarakat.

Bahan baku kerupuk kerang adalah kanji dan kerang darah, bawang, gula, garam dan penyedap rasa. Dalam proses pembuatannya Kerang di blender tanpa di cuci. Bumbu bumbu dihaluskan dengan cara diblender. Bumbu yang telah halus di campur dengan kanji (2 Kg kerang: $10 \mathrm{Kg}$ Kanji) dan ditambahkan kaldu kerang panas sedikit demi sedikit hingga adonan menjadi kalis dalam 
bak plastik. Selanjutnya adonan di cetak menggunakan tangan dengan ukuran sekitar 5 $\mathrm{cm}$ x $20 \mathrm{~cm}$. Selanjutnya dikukus pada dandang yang loyangnya di beri alas daun pisang dan diolesi minyak goreng. Pengukusan dilakukan selama satu jam. Seluruh proses ini memerlukan waktu 2 jam untuk setiap resepnya $(10 \mathrm{Kg})$. Setelah dikukus lontong kerupuk di iris iris setebal kurang lebih $3 \mathrm{~mm}$. Pengirisan lontong kerupuk menggunakan pisau biasa. Kerupuk yang telah diiris di jemur di bawah terik matahari menggunakan anjang anjang dari bambu. Bila sudah kering kerupuk tetap di jemur menggunakan alas karung plastik. Penjemuran dilakukan di pingggir jalan depan rumah, sehingga kerupuk banyak ditempeli debu. Setelah kering betul, dengan ciri kerupuk mudah dipatahkan dengan tangan, kerupuk di simpan di karung plastik dan siap di goreng. Penggorengan dilakukan di wajan yang penuh dengan minyak dan di tiriskan. Kerupuk yang telah digoreng di letakkan pada kantong plastik besar dan selanjutnya dilakukan pengemasan.

Pengemasan kerupuk ada dua macam. Pengemasan kerupuk kerang mentah dengan $1 \mathrm{~kg} /$ bungkus dan diberi label dengan tulisan Eni yang dilengkapi dengan nomor telefon. Kerupuk kerang mentah ini hanya dijual sesuai dengan pesanan. Harga satu $\mathrm{Kg}$ kerupuk kerang mentah Rp 27.000,(Duapuluh tujuh rupiah). Kemasan kerupuk matang (yang telah digoreng) dikemas dalam plastik sederhana tanpa label. Setiap bungkus berisi 5 lembar kerupuk. Kerupuk yang telah digoreng ini dijual dengan harga Rp. 400,(Empat ratus rupiah)/bungkus. Kerupuk kemasan matang setiap hari diambil oleh pemilik warung kopi. Pada Warung kopi di jual Rp. 500,- (lima ratus rupiah) setiap bungkusnya. Pembuat kerupuk kerang melayani lebih dari 100 warung kopi yang ada di daerah Pepe, Kalang anyar, Buncitan, Wedi, Blijon, Sedati, Gumoro, dan lain lain yang masih dalam kawasan kecamatan Sedati dan kecamatan Buduran.

Pada musim hujan ada kendala dalam proses pengeringan kerupuk, karena bila tidak dijemur kerupuk akan berjamur. Bila musim hujan produksinya menurun sehingga penghasilannya juga menurun. Permintaan kerupuk kerang goreng setiap harinya sangat banyak bahkan terkadang pembuat kerupuk kerang tidak sanggup memenuhinya karena keterbatasan tenaga, peralatan dan produksinya tergantung cuaca.

Kerupuk Kerang kaya akan protein, dan akan bertambah nilai gizinya bila dilakukan inovasi dengan menambahkan sayur sehingga lebih bermanfaat untuk kesehatan.

\section{Permasalahan Mitra}

Permasalahan utama pembuat kerupuk kerang adalah:

1. Kemampuan dan pengetahuan pembuat kerupuk kerang terbatas dalam hal:

a. Kerupuk diuleni menggunakan bak plastik yang tidak tahan panas, saat adonan di uleni dengan kaldu kerang panas maka adonan dapat tercemar bahan kimia dari plastik.

b. Kerang yang digunakan tanpa di cuci dan tidak di buang kotorannya. Hal ini membuat kerupuk kerang yang diproduksi tidak hygienis.

c. Pembuat kerupuk kerang kurang kreatif dan kurang inovatif. Kerupuk kerang untuk meningkatkan nilai gizi perlu di buat variasi dengan menambahkan aneka sayur.

d. Pengetahuan dan kemampuan cara pengemasan kerupuk kerang kurang, karena kemasan hanya pada kantong plastik tanpa label sehingga kurang menarik dan kurang mempunyai nilai jual.

e. Pengetahuan tentang hygienitas kerupuk kurang karena penjemuran kerupuk dilakukan di pinggir jalan sehingga kerupuk banyak tercemar debu.

2. Pengetahuan tentang strategi pemasaran kurang karena pemasarannya hanya mengandalkan pelanggan tetap yang mengambil di rumah.

3. Penjemuran yang hanya mengandalkan sinar matahari menyebabkan pada saat hujan tidak memproduksi kerupuk 
sehingga penghasilannya tidak ajeg (tidak rutin). Bila hujan tidak menentu maka harus bolak balik menjemur, hal ini sangat melelahkan. Kerupuk yang tidak kering akan jamuran dan bila digoreng rasanya kurang enak/masam.

4. Produksi terbatas sehingga tidak bisa melayani pesanan dalam jumlah banyak. Hal ini karena terbatasnya fasilitas pendukung proses pembuatan kerupuk kerang yang dipunya.

5. Bentuk kerupuk kerang tidak menarik karena kerupuk dicetak menggunakan tangan sehingga ukurannya tidak rata

6. Ketebalan kerupuk kerang tidak rata karena di iris secara manual. Hal ini mempengaruhi kualitas kerupuk saat digoreng.

7. Kerupuk di uleni dengan tangan. Hal ini menyebabkan adonan tidak tercampur rata dan terbatas dalam jumlah adonan.

\section{METODE PELAKSANAAN}

Untuk menyelesaikan masalah yang dihadapi mitra dilakukan melalui metode

1. Pelatihan,

2. Pendampingan dan

3. Pemberian fasilitas pendukung proses.

Pembuatan Kerupuk Kerang Asli dan Kerupuk Kerang campuran wortel

\section{Pemilihan bahan: cirri kerang darah}

segar: pada kerang yang masih ada cangkangnya: banyak cangkang yang terbuka, ini menunjukkan kerang masih hidup. Pada kerang kupas daging kerang padat dan terlihat utuh, warna daging kerang belum berubah dari aslinya yaitu merah ke orange, beraroma amis yang khas.

\section{Proses Pembuatan:}

Kerang darah segar masih bercangkang dicuci bersih, direbus dan diambil kaldunya. Kerang dikupas (dilakukan oleh pengupas kerang/penjual kerang). Kerang kupas dihilangkan kotorannya dan dicuci dengan air mengalir, selanjutnya di blender. Bumbu bumbu meliputi bawang, garam, gula pasir dihaluskan dengan cara di blender. Kerang yang telah diblender dicampur bumbu dan di campur dengan tepung kanji (tapioka) selanjutnya di uleni dengan menambahkan kaldu kerang panas sedikit demi sedikit. Bila adonan sudah kalis adonan di cetak dan dikukus pada dandang yang loyangnya telah diberi alas daun pisang. Setelah 1 jam pengukusan, ditunggu dingin dan kerupuk kerang siap di rajang/diiris tipis dan di jemur. Penjemuran dilakukan pada anjang anjang bambu yang agak tinggi dari permukaan tanah. Bila telah kering kerupuk kerang digoreng dan ditiriskan.

Pembuatan kerupuk kerang dengan tambahan wortel dilakukan dengan cara wortel di kupas di cuci bersih, selanjutnya di blender. Wortel yang telah diblender dicampur dengan kerang dan bumbu yang telah diblender. Selanjutnya proses sama seperti membuat kerupuk kerang asli.

Dalam proses ini untuk meningkatkan produksi maka diperlukan teknologi tepat guna yaitu:

1. Mesin pengaduk adonan

2. Pencetak lontong kerupuk

3. Mesin perajang Kerupuk

4. Alat perekat kemasan

\section{Pengemasan Kerupuk Kerang}

Pengemasan dilakukan pada plastik bening polypropylene yang tahan panas dengan ketebalan $0.05-0.10 \mathrm{~mm}$ dan lebar $15-18 \mathrm{~cm}$. Plastik disablon atribut (komposisi, merek, tanggal kedaluarsa dan nama produsen, nomor PIRT). Kerupuk dimasukkan pada kantong plastik menggunakan tangan bersarung tangan, selanjutnya kemasan direkat menggunakan heat sealer.

\section{Cara mendaftarkan untuk memperoleh nomor PIRT dari DEPKES}

Pembuat kerupuk kerang didampingi datang ke kantor Departemen Kesehatan untuk mendaftarkan nomor PIRT dari DEPKES dengan membawa contoh hasil produksi. Pembuat kerupuk harus melengkapi data yang dipersyaratkan oleh DEPKES guna memperoleh nomor PIRT. Disamping itu 
pembuat kerupuk kerang didampingi untuk mengikuti seminar dalam rangka memperoleh nomor PIRT dan siap menerima kunjungan oleh petugas DEPKES.

\section{HASIL DAN PEMBAHASAN}

\section{Hasil}

Setelah dilakukan Pelatihan, Pendampingan dan Pemberian fasilitas pendukung proses maka hasilnya adalah

1. Pembuat kerupuk kerang meningkat pengetahuan dan ketrampilannya dalam hal: a. Pemilihan bahan utama kerupuk kerang yaitu kerang berkualitas baik.

b. Mampu memproduksi kerupuk kerang asli dan kerupuk kerang dengan campuran wortel yang sehat, bergizi serta hygienis.

c. Mampu mengemas hasil kerupuk olahannya secara baik.

2. Telah diperoleh nomor PIRT dari DEPKES

3. Mampu memperluas daerah pemasaran kerupuk kerang dan kerupuk kerang campuran aneka sayuran.

4. Produksi Kerupuk kerang meningkat

5. Penghasilan pembuat kerupuk kerang meningkat dan rutin (ajeg)

Tabel: Hasil sebelum dan sesudah di lakukan Pendampingan

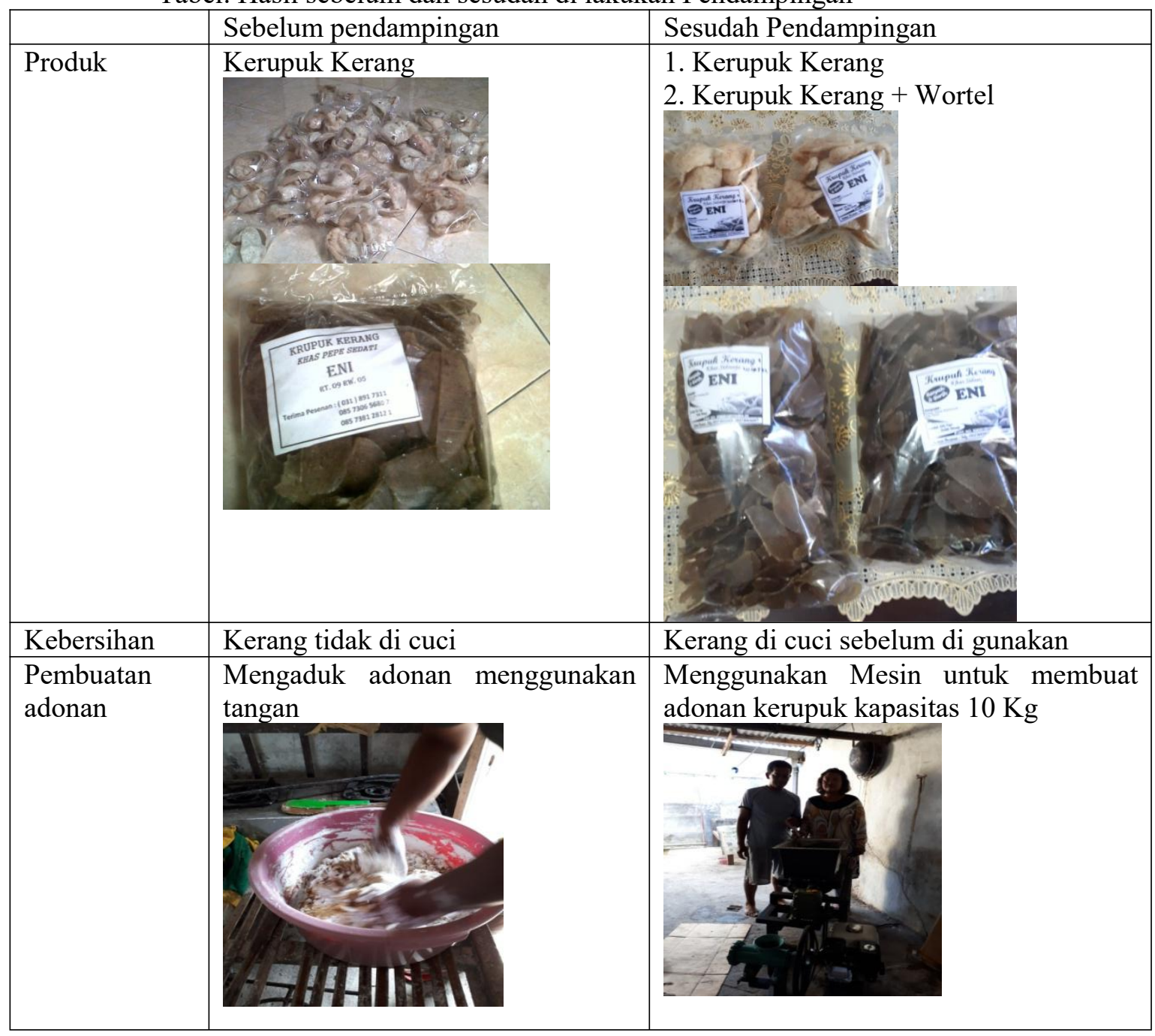


PENAMAS ADI BUANA

Volume 04, Nomor 1, 01 Juli 2020

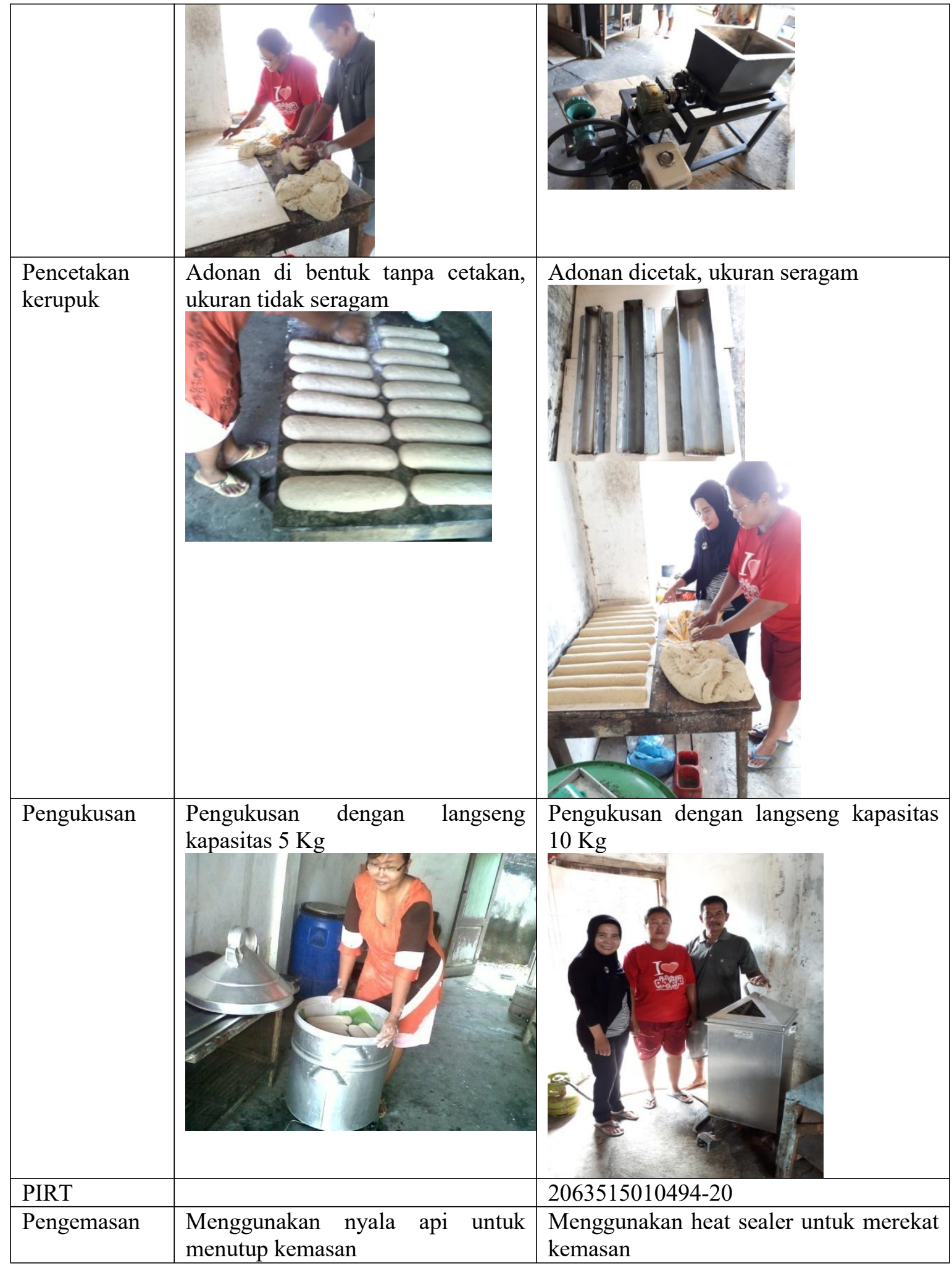




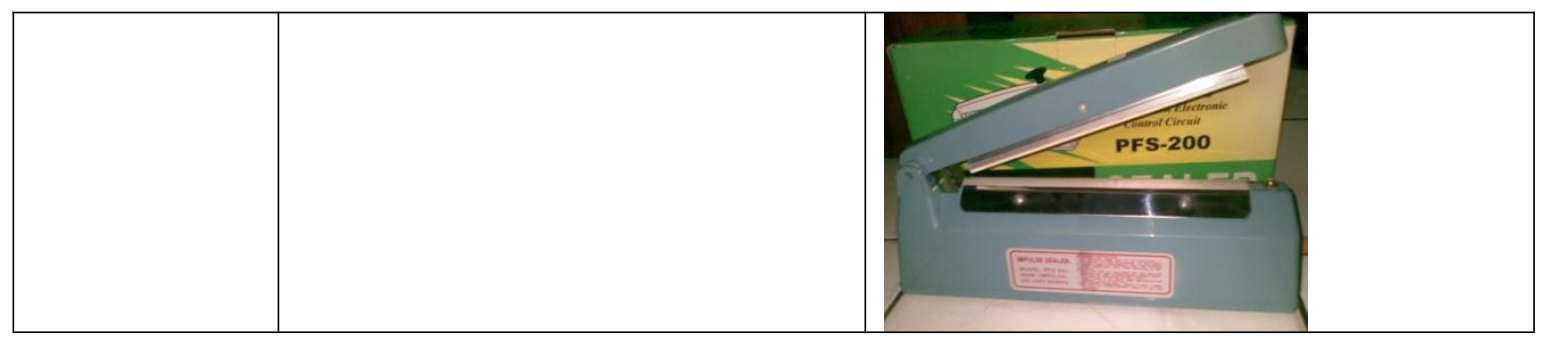

\section{Luaran:}

1. Produk Kerupuk Kerang asli dalam kemasan yang baik dan beratribut serta telah memperoleh nomor PIRT dari DEPKES.

2. Produk Kerupuk kerang dengan penambahan wortel dalam kemasan yang baik dan beratribut.

3. Teknologi tepat guna mesin pengaduk adonan

4. Pencetak adonan kerupuk

\section{Pembahasan}

Kerupuk adalah makanan kering yang dibuat dari kanji, tepung terigu, tepung beras dengan atau tanpa penambahan bahan makanan lain yang disiapkan dengan cara menggoreng atau memanggang sebelum disajikan. Kerupuk dikenal sebagai teman makan nasi ataupun sebagai makanan kecil (snack). Kerang darah banyak diolah hanya dengan di rebus, dibuat masakan dan sate. Usaha peningkatan nilai ekonomis kerang belum banyak dilakukan, sehingga perIu adanya diversifikasi bentuk produk olahan. Kerupuk kerang merupakan salah satu produk olahan dari kerang. Kandungan nutrisi kerang yaitu dari sepuluh kerang hanya mengandung 100 kalori dan hanya 0.2 g lemak jenuh. Kerang juga merupakan sumber mineral yang baik yaitu tembaga, yodium dan zinc serta zat besi dan selenium. Kerang juga mengandung vitamin A, E dan B kompleks. Dengan demikian kerupuk kerang ini mempunyai nilai gizi yang cukup tinggi.

Pada program IbM ini telah dilakukan penambahan kerupuk kerang dengan wortel. Penggunaan wortel ini dengan alasan bahwa wortel mempunyai kandungan gizi yang baik yaitu setiap $100 \mathrm{gr}$ wortel mengandung 41 kalori, tidak mengandung lemak maupun kolesterol. Wortel mengandung karoten vitamin A maupun B. Beta karoten merupakan antioksidan yang sangat kuat. Wortel juga mengandung mineral yaitu tembaga, Kalsium, kalium, mangan dan fosfor. Dengan demikian penambahan wotel akan menambahn nilai gizi dari kerupuk kerang. Hasil kerupuk kerang yang ditambah wortel itu penambahan wortel membuat penampilan kerupuk lebih bagus, lebih renyah dan lebih gurih.

Pada program IbM ini dihasilkan kerupuk yang lebih hygienis karena bahan semua dicuci sebelum di gunakan. Kapasitas produksi lebih meningkat karena semula adonan di uleni menggunakan tangan yang hanya mampu membuat $5 \mathrm{Kg}$ sekali adonan sedangkan dengan pemberian fasilitas mesin pengaduk adonan maka pembuatan adonan meningkat menjadi $10 \mathrm{Kg}$ sekali pembuatan adonan. Pengukusan adonan kerupuk mempunyai kapasitas lebih besar yaitu $10 \mathrm{~kg}$ dimana sebelumnya $5 \mathrm{Kg}$. Kerupuk bentuknya lebih bagus dan seragam karena sebelum IbM pembuatan kerupuk tanpa di cetak. Dengan pemberian fasilitas cetakan kerupuk maka bentuk kerupuk seragam. Ketebalan kerupuk rata karena dirajang menggunakan mesin perajang dimana sebelumnya kerupuk di rajang secara manual. Kerupuk yang sebelumnya dikemas dalam plastik yang direkat menggunakan api sekarang kemasan direkat menggunakan heat sealer. Label pada kemasan sekarang sudah ada merk, komposisi dan No PIRT. Kerupuk kerang ini telah mendapat no PIRT dan DepKes. 


\section{KESIMPULAN DAN SARAN}

\section{Simpulan}

Kesimpulan dari pelaksanaan pengabdian ini adalah

1. Pembuat kerupuk kerang telah mampu memilih bahan kerang yang berkualitas.

2. Pembuat kerupuk kerang telah mampu membuat kerupuk kerang yang hygienis

3. Penampilan dari kerupuk kerang lebih bagus karena telah di cetak sehingga ukurannya seragam

4. Produksi kerupuk kerang tidak hanya berbahan kerang tetapi juga di kombinasikan dengan wortel

5. Telah Mendapatkan Nomor PIRT.

6. Produksinya meningkat sehingga penghasilannya meningkat.

\section{Saran}

1. Penggunaan sayuran tidak harus diblender tetapi bisa juga di buat tepung/serbuk sayur. 2.Kerupuk di buat varian rasa yaitu pedas dengan tingkatan yang berbeda

\section{REFERENSI}

Almatsier S. 2002. Prinsip Dasar Ilmu Gizi. Jakarta: PT. Gramedia Pustaka Utama.

Inswiasri, dkk.,1993, Penelitian tentang Pencemaran logam berat dalam Ikan segar dan Kerang dari Teluk Jakarta, Laporan Akhir Penelitian.

Jaunch dan Glueck. 1995. Manajemen Strategis dan Kebijakan Perusahaan.Erlangga. Jakarta.

Kotler, Philip. 2000. Manajemen Pemasaran : Analisis, Perencanaan,Implementasi, dan Kontrol. Jilid I. Edisi Milenium. Prenhallindo. Jakarta.

Mubarak, H., 1997, Penentuan lokasi budidaya Kerang darah di Perairan Blanakan Jawa Barat, Jurnal Penelitian, Perikanan laut Jakarta: 42-49

Walujodjati, A dan Darmanto, 2005, Rancang bangun Mesin Pengering Kerupuk Untuk industri Kecil Kerupuk, Momentum, Vol, 11, No1 
PENAMAS ADI BUANA

Volume 04, Nomor 1, 01 Juli 2020
P ISSN 2622-5727

E ISSN 2622-5395 